\title{
Livelihood Strategy After the Eruption of Kelud Mountain in Sugihwaras Village Ngancar Subdistrict Kediri Regency (Case Study : the Society in Sugihwaras Village)
}

\author{
Dian Ayu Larasati* \\ Geography Education Department \\ Faculty of Social Sciences and Law, \\ Universitas Negeri Surabaya \\ Surabaya, East Java, Indonesia \\ dianlarasati@unesa.ac.id \\ Ali Imron \\ Social Science Education Department \\ Faculty of Social Sciences and Law, \\ Universitas Negeri Surabaya \\ Surabaya, East Java, Indonesia \\ aliimron@unesa.ac.id
}

\author{
Sukma Perdana Prasetya \\ Social Science Education Department \\ Faculty of Social Sciences and Law, \\ Universitas Negeri Surabaya \\ Surabaya, East Java, Indonesia \\ sukmaperdana@unesa.ac.id \\ Fatin Nurahma \\ Graduate Student of Geography \\ Education \\ Faculty of Social Sciences and Law, \\ Universitas Negeri Surabaya \\ Surabaya, East Java, Indonesia \\ fatinnurahma@gmail.ac.id
}

\author{
Nuansa Bayu Segara \\ Social Science Education Department \\ Faculty of Social Sciences and Law, \\ Universitas Negeri Surabaya \\ Surabaya, East Java, Indonesia \\ nuansasegara@unesa.ac.id
}

\begin{abstract}
Sugihwaras village is included in The DisasterProne Areas. Kelud Mountain has erupted causing damage in various fields. However, the society in Sugihwaras still stayed to survive in their home despite of the eruption. The purpose of this study is to identify and describe the livelihood strategy by the society in Sugihwaras. This study was qualitative with case study approach. The setting of the study was at Sugihwaras Village Ngancar Subdistrict Kediri Regency. Data were collected using deep interviews. Data were analyzed using three stages such as: data reduction, data presentation and conclusion. The results of this study showed that the society responded actively and survived from to the eruption in 2014 through five strategies namely: 1) The human capital, average formal education of society was high school level that can affects to the job they get, 2) The natural capital, nature harnessed was optimally utilized by the society to support their life, 3) The social capital, society had a strong relation and the implementation of values in the society going very well, 4) The physical capital, most of the society had house that permanently built and ownership of communication device to facilitate information on mountain developments, 5) The financial capital , the society had personal savings to rebuild all the damage after the eruption. There are many tourism objects built by the company there. Thus, the tourism object was not owned personally by the society, but by the company.

Keywords: strategy, capitalism, society
\end{abstract}

\section{INTRODUCTION}

Indonesia is a country in the ring of fire area because Indonesia is surrounded by tectonic plates with chain of volcanoes make Indonesia has the disaster volatile status of volcanic eruption. Volcanoes in Indonesia spreading almost all over the island, including Java. There are several volcanoes in East Java such as Kelud Mountain. Kelud
Mountain is located in three regencies, namely Kediri Regency, Blitar Regency and Malang Regency.

[1] says that "disaster is an event or series of events that threaten and disrupt society's lives and livelihoods caused by natural factors and / or non-natural factors as well as human factors resulting in human casualties, environmental damage, property loss, and psychological impacts". Natural disasters in general will have a big effect on the socioeconomics life of society because human life cannot be separated from nature. A natural disaster that cannot be avoided by humans is the eruption of volcanoes.

The problem of disaster will have a greater impact when it occurs in rural areas where the economy is still unable to be independent. The majority of rural society worked in the agricultural sector with purpose of agricultural land as a source of income. According to [2], "agriculture is a way of life so it is not only involved the agribusiness aspects but also social and cultural aspects. So, the eruption of Kelud Mountain that occurred in 2014 , it can certainly bring a lot of change to the society's condition".

\section{Automated assumption generation}

The society in Sugihwaras Village responded to the phenomenon of Kelud Mountain eruption by adapting to make possible adjustments for survival and sustainability. Based on the background description above, research will be conducted with the title "Livelihood Strategy After The Eruption of Kelud Mountain In Sugihwaras Village Ngancar Subdistrict Kediri Regency (Case Study The Society In Sugihwaras Village)". The purpose of this study is to identify and describe how the livelihood strategy by the society of Sugihwaras Village after the eruption of Kelud Mountain. 


\section{METHOD}

This study was qualitative with case study approach. The main instrument of qualitative was the activeness of researchers on collecting data. The setting of this study was in Sugihwaras Village Ngancar Subdistrict Kediri Regency. The subject was the society of Sugihwaras Village. Researchers was using purposive sampling technique to determine the next informant.

The data sources were primary and secondary data. The primary data was depth interview, the secondary data were society's data obtained from the monograph's data of Sugihwaras Village, the impact of the 2014th Kelud Mountain eruption from agencies related to this research such as the Canter for Volcanology and Geological Hazard Mitigation (PVMBG), Disaster Management Agency Regional (BPBD) and Village Government. According to[3] explained that data collection techniques and analysis of relevant data obtained from natural situations. Data were collected using deep interviews and documentation. Data were analyzed using Miles and Huberman model [4] such as data reduction, data presentation and conclusion. The validity of this data study was using credibility, transferability, dependability and confirmability tests.

\section{RESUlTS AND DisCUSSION}

Sugihwaras Village located in the second Disaster-Prone Area causing Sugihwaras Village has a serious impact caused by Kelud Mountain. The theory of livelihood strategies by the society of Sugihwaras Village after the eruption of Kelud Mountain in 2014th is a theory by Chambers and Conway as a survival strategy [5].

The results of interviews with informants as the Village Head showed changes in life patterns and livelihoods by the society after the eruption. The existence of new tourism object in Sugihwaras Village caused by a request from the Kediri Regency Government to the Reginal Plantation Area (PDP) Margomulyo. The description of the results of the interview with the informant as the Director of Company Production about tourism management showed that all tourism assets owned by the company utilized Human Resources from the Sugihwaras society, this were in line with the capitalism theory studied by [6].

\section{A. The Social Condition of Society in Sugiwaras Village}

The result of this study showed that society had awareness on responding the eruption occurred on 2014th in Kelud Mountain, this is supported both on a good communication and transmission the information from The Center for Volcanology and Geological Hazard Mitigation (PVMBG) also a good cooperation between society and the village government.

The definition of possibilism by [7] explained that humans are intelligent creatures, and with their ability humans can respond to what nature provided. That definition showed that the society in Sugihwaras Village were reflecting an attitude that lead to possibilism.
The results of this study showed that the disruption of life stability and changes in social order due to eruption did not affect on social relations in Sugihwaras Village. A strong relation created by the quick response of society to help each other and do mutual cooperation to repair damage.

The social relation of society by [8] showed that social contact can communicated messages between individuals who are interconnected and it was based on human consciousness as social beings to help each other.

The theory of relationship between human and environment showed that the social relation tends to be possibilism. It showed from the closeness and harmony in society on continuing life after the eruption.

The result of this study showed that the society responded actively and survived from the eruption. The adaptation was in different ways, this showed that society survived from the condition. All the informants explained that no society had the desire to migrate permanently to a place that safe from volcanic eruption.

In connection with theory between human and environment showed that society affected by eruption in the study area were possibilism. This is showed by the ability from the society to kept them a lived.

\section{B. The Livelihood Strategy of Society}

The result of this study showed that the society had jobs that relied on natural resources, the society used the environmental condition as a source of work because there were several attractions built. The society's skills in implementing the economy were obtained from formal education and work experience from the colleagues.

The spatial aspects explained that society utilized the natural potential as a livelihood sources. The society average formal education of society was high school level that can affects to the job they get.

The result of this study showed that natural capital was the resources that can be utilized by the society. The Natural Potential Resources and the environment supported the society's economy in any fields, especially many tourism object opened after the eruption by The Plantation Government Area (PDP) Margomulyo in order of Kediri Regency Government that can supports the economy for the society in Sugihwaras Village.

The spatial aspects showed that natural capital used by all the society levels on livelihood strategies by utilized the natural potential around the village. The society used the natural potential as a resource in tourism object by working on the tourism object sector which entirely utilized the potential of natural beauty in Sugihwaras Village.

The result of this study showed the social capital were strong not only with the social lives but also with disaster agencies.

The good relationship in society were caused by various factors, namely tolerance and compassion that were strongly intertwined.

The social capital were a wealthy for the society's relations such as norms, networks, group's membership, relations based on trust, exchange of rights that can reduced the costs, and other. According to [9] explained that every individual had the desire to make a relation with others. 
The spatial aspects explained that the social capital between the society and outsiders were very good. This were related to the geographical conditions which were rural areas that can make the society's social level created very well.

The result of this study showed that ownership of houses, transportations, and farming tools were the main things on supporting the economy because farming were the necessity for the society in Sugihwaras Village.

The spatial aspects explained that the society who had jobs provided income also had house that permanently built and ownership of communication device to facilitate information on mountain developments this were closely related to the environmental conditions.

The result of this study showed that to repaired damage after eruption, the society used variety of different methods. The society who had enough savings to repair the damage were employ the neighbors who had no enough savings so they can earn a temporary income from worked for the neighbors who had enough money. Tis study also showed that most of society had savings for the children's education.

The spatial aspects explained that the society were able to repaired all the damages that occurred after the eruption by their savings and the government assistance. The society who worked as pineapple farmers made loans from banks that were used in the planting season before the eruption should return it to the bank

\section{The Capitalism}

The result of this study showed that many tourism object after the eruption on 2014th occurred. The tourism object were built by a regional company in Sugihwaras Village namely Margomulyo Plantation Regional Company (PDP). The company not only built and managed all the tourism object but also had full ownership because the company was the owner and investor from all the assets.

According to Mansour Fakih in [6] theoretically capitalism is a concept that aim for capital accumulation through investment processes for the capital fertilization, so each individual was encouraged to compete the production's increases by utilized the human resources, technology and natural resources.

The research showed that society got nothing from the relationship between society and company for tourism object that built in Sugihwaras Village. According to [10] explained the investor were the ownership for all the assets. The society had no rights for the tourism object that made the society only got wages as the employee from each tourism object, society also allowed to sell along plantation location as the tourism object because many tourists coming here.

The society received a small profit from selling at tourism object because of the tourist's presence, on the other side the company received more advantage over the tourists' interest in the natural beauty of the village and its society's products.

\section{CONCLUSIONS AND SUGGESTIONS}

The society responded with ideas to act (trend to behave) and not surrendered in responding to the disaster.
The society actively maintained social relation by mutual assistance to repair the damage. The society's responses, the ability to maintained social relation and the ability to adapted after the eruption showed that society were generally possibilism. Some of society were determinism because they recognized that already known the characteristics of Kelud Mountain that made them did not want to replaced to a safer place when the eruption occurred.

The investor's role were built, manage and develop the potential in Sugihwaras Village Ngancar District Kediri Regency.

\section{REFERENCES}

[1] "Undang-Undang No 24 Tahun 2007 tentang Penanggulangan Bencana," Jakarta.

[2] A. Turasih, "Sistem Nafkah Rumah Tangga Petani Kentang di Dataran Tinggi Dieng (kasus Desa Karangtengah, Kecamatan Batur, Kabupaten anjarnegara, Provinsi Jawa Tengah)," vol. 6 , no. 2, pp. 196-207, 2012

[3] D. Satori, Metodologi Penelitian Kualitatif. Bandung: Alfabeta, 2013.

[4] M. Sugiyono, Metode Penelitian Kuantitatif, Kualitatif, dan $R \& D$. Bandung: Alfabeta, 2009.

[5] Zamroni, "Desa Mengembangkan Penghidupan Berkelanjutan Dapat diunduh," Universitas Negeri Islam, 2015. [Online]. Available: http://digilib.uin-suka.ac.id/25503/. [Accessed: 05Nov-2018].

[6] A. Semekto, Kapitalisme, Modernisasi, dan Kerusakan Lingkungan. Yogyakarta: Genta Press, 2008.

[7] Supriya, Konsep Dasar IPS. Bandung: Universitas Pendidikan Indonesia, 2007.

[8] S. C Soekanto, Sosiologi Suatu Pengantar, IV. Jakarta: PT Raja Grafindo Persada, 2006.

[9] W. Murtiningsih, Para Filsuf Dari Plato Sampai Ibnu Bajjah. Yogyakarta: IRCiSoD, 2012.

[10] G. Wiradi, Kapitalisme perkebunan dan Konsep Kepemilikan Tanah oleh Negara. Yogyakarta: Insist Press, 2002. 